\title{
BUILDING INFORMATION MODELLING AS A CONSTRUCTION MANAGEMENT TOOL IN NIGERIA
}

\author{
IHUOMA ONYINYECHI ONUNGWA, NNEZI UDUMA-OLUGU \& JOSEPH M. IGWE \\ Department of Architecture, University of Lagos, Nigeria
}

\begin{abstract}
Building Information Modelling (BIM) is a process that enhances construction management. One of the major advantages of the BIM is its ability to develop a model that can be used from the initial design to construction and occupancy of the building. In view of this advantage, it can be regarded as a central aspect of construction management. However, in Nigeria, the utilization of BIM as a vital tool for construction management remains at the preliminary stage. Therefore, the purpose of this paper is to evaluate the effect of BIM as a tool for construction management in Nigeria and, through this, identify measures to improve or, otherwise, facilitate its use in the Nigerian building industry. To realize this, structured questionnaires were distributed to AEC firms selected through the simple random sampling method. Discussions were also conducted among peers and showed a number of barriers to the use of BIM, which include: lack of support from leadership in the offices, lack of communication among consultants from diverse fields, and lack of awareness on how to use BIM. The data analyzed indicate that BIM has a high impact on the effective supervision of projects, programming and resolution of conflicts during construction. BIM is, therefore, significant in a bid to realizing a high level of efficiency in construction. Particularly, it can guide subcontractors and fabricators in submitting their inputs at an early stage in order to improve the co-ordination of projects during construction. Moreover, given the high rate of building collapse in Nigeria, due mainly to inefficient construction management, a research on BIM as a tool for building construction is necessary. Worth considering as well is that despite advances in the use of BIM, the processes by which buildings are constructed in Nigeria remain unchanged. The paper, therefore, recommends the development of innovative processes that will include BIM in construction management, more communication and collaboration among diverse professionals and, indeed, increased publicity on the benefits derivable from using BIM in construction management.
\end{abstract}

Keywords: adoption, building information modeling, collaboration, Nigeria, construction management.

\section{INTRODUCTION}

Building Information Modeling (BIM) is a process that can improve construction management because of its integrated nature. It is used in developing a collaborative construction process that includes designing, building, operating and maintaining buildings. A BIM would normally be created at the early stages of the design. It would also undergo an update as the design is upgraded and used by the construction team, and improved continuously as the facility is built.

Globally, BIM usage is transforming the construction industry. It is changing the process of design and construction of buildings. Hassan and Yolles [1] posit that BIM entails a sevendimensional process. The 3D modeling process extends to scheduling and sequencing (4D), cost estimating (5D), sustainable design, also termed Green Design (6D) and facility management (7D). BIM is a new approach to design, depending on the level of collaboration between the Architects, Client, Engineers, Building services, Manufacturers, Contractors and other consultants. It is a team approach in which the inputs of all the professionals in the design are captured in the same model.

The collapse of buildings and other structural failures have become major problems in Nigerian construction industry. Hence, BIM as a model, when used during the course of a 
project, is capable of aiding efficiency in the construction of buildings and reducing problems that may occur during construction. There is however a dearth in the application of BIM in building construction in Nigeria. In this regard, the primary purpose of this paper is to investigate the use of BIM as a construction management tool in Nigeria and evaluate the factors that promote its use. To this extent, the innovations that have been introduced as to how BIM can be applied will be identified.

Few studies have been done focusing on the use of BIM as a veritable instrument that can be applied in the construction of buildings in Nigeria. Some studies have however considered the benefits of BIM in the building industry. Abubakir et al. [2], for instance, studied contractor's perception of factors affecting building information modelling in the Nigerian Construction industry. But this paper evaluates the application of BIM as a potent tool for the management of building construction in Nigeria. It as well explores the required incentives that can encourage the effective utilization of BIM.

\subsection{Aim and objectives}

The main objective of this study is to investigate the use of BIM in Nigeria and explore the incentives for its effective utilization as a tool for construction management. Other subsidiary objectives are:

1. To explore BIM as a tool for construction management in Nigeria.

2. To identify and discuss the approaches needed to improve the use of BIM among stakeholders in the Nigerian construction industry.

3. To identify and discuss barriers militating against the use of BIM in construction activities.

\section{LITERATURE REVIEW}

There have not been many studies on BIM as a tool for construction management in Nigeria. It thus makes literature on the subject limited. Given this, this review will focus on the BIM as a tool applied to the management of construction. It will show how the introduction of this model has energized, if not strengthened the operational reach of stakeholders in the construction industry. By showing the impact of BIM on construction management, the review will also emphasize the benefits that can be derived when it is applied. As it shows the advantages that can be derived from BIM, this review also gives attention to factors that impede its application in Nigeria. Important as well, the innovations that have so far been introduced by the use of BIM are also highlighted.

\subsection{BIM as a construction management tool}

The growth of BIM has brought about new methods of construction management and project delivery. However, in Nigeria and other developing countries, this has not been the case. As Kiani et al. [3] have observed, "The continued growth of BIM has prompted new contractual arrangements of which the best known is Integrated project delivery (IPD)". This enables the costs of subcontractors and fabricators to be established early in the design process. However, this has not been the case in Nigeria. In AEC firms which use BIM, construction is still based on the traditional design-bid-build process. The inherent advantages that can be derived from using BIM as a construction management tool have not been utilized. 
"With the coordinating capability of Building Information Modeling (BIM) software, like Autodesk Revit, ArchiCAD and the use of IPD, companies have been seeing a reduction in costs and a more effective use of time" [3]. These are advantages relevant to construction management. "The ability to utilize BIM to virtually construct a building prior to construction of the actual building provides an effective means to check its constructability in the real world and to resolve any uncertainties during the process" [4]. Hence, BIM is a valuable tool for construction management. However, in Nigeria, BIM is still mainly used by Architects for presentation of drawings. The advantages in construction management have not been tapped into. Some companies have started the design build approach and are able to get inputs from subcontractors at an early stage but these are few. In construction management, several key performance indicators (KPI's) have been identified. Brewer and Mendelson [5] identified these as cost, time, and quality, team performance, communication, stake-holder and human resource management [5]. The effects of BIM on these KPI's will be studied in the next section.

\subsection{Benefits of BIM}

There are various benefits that can be derived from using BIM. These include: better coordination, synchronization and sequencing of projects, and allowing all project participants to access and interrogate project information. At an advanced level, BIM enables better clash detection [6]. Other benefits include: ability to visualize what is to be built in a simulated environment, higher reliability of expected field conditions, allowing for opportunity to do more prefabrication of materials off site [7]. The building design development can continue with the provision of automatic bills of material and generation of automatic shop drawings for everything from structural steel to sheet metal duct fabrication, to fire protection and piping fabrication, to electrical cabling and bus duct layouts [8].

BIM can potentially increase the efficiency, quality and productivity of construction projects. This it can do by reducing the number of mistakes and incompatibilities, providing more accurate and up-to-date information, and by giving a more illustrative and accessible exposition of a building [9]. BIM streamlines the design process across the company and facilitates automation of emails via knowledge database.

\subsection{Barriers to adoption of BIM as a construction management tool in Nigeria}

Despite the advent of BIM, many AEC companies continue to use established work procedures for construction management. Similarly, the integrated concept of BIM increases risks and liabilities to different parties involved [10]. This creates problems when vendors and other consultants make inputs to the BIM. The BIM systems create big files, manages and transfers them. But it is usually difficult to do so because of the problems in internet facilities and power supply in Nigeria.

There are many barriers to the adoption of BIM. Key of the barriers is the lack of skilled personnel in the construction industry Most architects train themselves or learn on the job. Therefore, they are usually not aware of new trends in technology, especially the capabilities of the software Another factor that militates against the adoption of BIM is the "Fear of Change" [1]. Using BIM means a change of mindset from developing drawings with lines to developing drawings in three dimensions putting in walls, windows, doors and other building components.

Lack of constant electricity and lack of internet connectivity affect output of work the offices [2]. In the same way, constant use of generators increases cost of running the offices. 
To adequately use BIM, Internet connection must be available. Internet, for instance, has to be available to get drawings from a vendor site. But Internet is not readily available in Nigeria. As a result, if it is to be made available, will increase the cost of production. Noteworthy also is that many professionals in the construction industry are not aware of latest developments in technology.

BIM usually involves series of activities, highly skilled personnel and a lot of data input. To ensure its efficiency, the conditions for its operation need to be provided. There must also be institutional support from the Architects and the Engineers. Without this, the fragmentation which currently exists in the industry will continue, despite the advent of new technology. In Europe and USA, Architects and Engineers have been able to integrate their works in the same BIM model. This is not the case in Nigeria. Fragmentation still exists in the construction industry

\subsection{Innovative approaches in use of BIM as a construction management tool}

The construction community has observed a shift from the 3D visualization aspect of BIM to workflow specific tools such as installations, verifications, sequencing and estimating [11]. New technologies such as cloud computing and widespread use of mobile phones have also created easy access to stored information. Successful BIM requires new processes, new technologies and new behaviors [11]. Of these three, new behavior is the most difficult to achieve.

In order for BIM to be effectively utilized as construction management tool in Nigeria, there is a need for changes from existing mindset. Innovative approaches to construction management must have to be developed. The most common approach to construction in Nigeria is the design-bid-build-process. However, this does not work well with the Integrated project approach of BIM. Some Nigerian companies have developed the design and build process. It is easier for these companies to use integrated project delivery process where inputs can be got from fabricators and subcontractors early in the design process. In this instance, new processes have to be developed in the construction process to accommodate the new technologies in BIM. On its part, BIM involves a collaborative approach to construction that combines various disciplines so as to build a structure in a virtual and visual environment [12]. To do this requires an efficient collaborative team of professionals. Collaborative team entails an assemblage of relevant knowledge, skills and attitude to work. In the same vein, Collaborative environment denotes institutional support, while collaborative processes are effective communication, clarity and conflict resolution processes [12].

\section{RESEARCH METHODOLOGY}

Different methods were used to analyze and discuss the data chosen for this research. For the purpose of this study, structured questionnaires were distributed to Architects, Engineers and other professionals in the construction industry. The questionnaires were organized by using theories such as Technology acceptance models and Task technology fit theories identified in the field.

Questions were developed to highlight the use of BIM as construction management tool. Similarly, questions regarding the level of its acceptance for construction management and measures that will encourage the use of BIM were also developed in the study. Research methodologies used by other scholars were also studied. Dim et al. [13] used case studies of different projects for their research on managing change process with BIM implementation 
by public and private investors in Nigeria while Oladapo [14] used questionnaires to survey participants in AEC industry.

\section{FINDINGS AND DISCUSSION}

A bulk of the respondents $(75 \%)$, were from firms within Lagos, $18.8 \%$ were from other southwestern states, while $6.3 \%$ were from the South South region of Nigeria. The highest group of respondents, were businesses that had been in operation between 11 and 15 years $(37.5 \%)$, followed by those between 1 and 5 years $(31.3 \%) .18 .8 \%$ of the respondents have been in business for over 21 years (Table 1). The least number of respondents were those whose business were $6-10$ years old $(12.5 \%)$. The respondents cut across the demographics reflecting the views of both those who have been long in practice and those who are relatively new to practice. $81.3 \%$ of the AEC firms interviewed use Autodesk Revit in their office while $18.7 \%$ use ArchiCAD.

Table 1: Analysis of socio-economic variables. (Source: field survey, 2015.)

\begin{tabular}{|c|c|c|c|c|c|}
\hline Variable & Characteristics & Freq. & $\%$ & Mean & Total \\
\hline \multirow[t]{3}{*}{ Address } & Within Lagos & 12 & 75.0 & & \\
\hline & South West & 3 & 18.8 & & \\
\hline & South South & 1 & 6.3 & & 16 \\
\hline \multirow[t]{4}{*}{ Years in business } & $1-5$ years & 5 & 31.3 & & \\
\hline & $6-10$ years & 2 & 12.5 & & \\
\hline & $11-15$ years & 6 & 37.5 & & \\
\hline & Over 21 years & 3 & 18.8 & $10.8 \mathrm{yrs}$ & 16 \\
\hline \multirow[t]{4}{*}{ Total no. of employees } & $1-5$ staff & 8 & 50.0 & & \\
\hline & $6-10$ staff & 6 & 37.5 & & \\
\hline & $11-15$ staff & 1 & 6.3 & & \\
\hline & Over 21 staff & 1 & 6.3 & 7 staff & 16 \\
\hline \multirow[t]{3}{*}{$\begin{array}{l}\text { What kind of projects do } \\
\text { you do? }\end{array}$} & $\begin{array}{l}\text { Mostly } \\
\text { residential }\end{array}$ & 1 & 6.3 & & \\
\hline & Commercial & 1 & 6.3 & & \\
\hline & All types & 14 & 87.5 & & 16 \\
\hline $\begin{array}{l}\text { Do you use any building } \\
\text { information modeling } \\
\text { software in your practice? }\end{array}$ & Yes & 16 & 100.0 & & 16 \\
\hline \multirow[t]{2}{*}{$\begin{array}{l}\text { If yes, which software do } \\
\text { you use? }\end{array}$} & $\begin{array}{l}\text { Autodesk } \\
\text { Revit }\end{array}$ & 13 & 81.3 & & \\
\hline & ArchiCad & 3 & 18.7 & & 16 \\
\hline
\end{tabular}


Question 1: How has the use of BIM solutions improved construction management?

Construction programming, supervision of jobs, quality of completed jobs and energy efficiency ranked the highest with a mean value of 4.31. BIM, however, had a low impact on estimation of costs, and safety (Table 2).

Question 2: What premium would you place on these factors as the barriers to adoption of Building information modeling in Lagos, Nigeria?

The major factors that impede the adoption of BIM were identified as lack of skilled personnel and lack of internet connectivity with a mean value of 3.75. Reluctance of other stakeholders, lack of awareness of technology and lack of BIM object libraries were also identified as factors that prevent its adoption (Table 3). This is shown in the review of literatures that has been done previously in this study. The analysis of data also shows that cost of hardware and software, frequent power outage, lack of contractual documents and fear of change were identified as having the greatest negative impact on the adoption of BIM in Nigeria.

Table 2: Analysis of impact of BIM on construction management. (Source: field survey, 2015.)

\begin{tabular}{|c|c|c|c|c|c|c|c|c|c|}
\hline \multirow[t]{2}{*}{ Variables } & \multicolumn{5}{|c|}{ Response } & \multicolumn{4}{|c|}{ Descriptive } \\
\hline & 1 & 2 & 3 & 4 & 5 & Mean & Rank & $\begin{array}{l}\text { Relative } \\
\text { index }\end{array}$ & Extent \\
\hline $\begin{array}{l}\text { Construction } \\
\text { programming }\end{array}$ & - & - & 2 & 7 & 7 & 4.31 & 2 & 1.01 & High \\
\hline Supervision of jobs & - & - & 1 & 9 & 6 & 4.31 & 2 & 1.01 & High \\
\hline $\begin{array}{l}\text { Quality of completed } \\
\text { jobs }\end{array}$ & - & - & 2 & 7 & 7 & 4.31 & 2 & 1.01 & High \\
\hline Energy efficiency & - & - & 2 & 7 & 7 & 4.31 & 2 & 1.01 & High \\
\hline Time of completion & - & - & 2 & 8 & 6 & 4.25 & 3 & 1.00 & High \\
\hline $\begin{array}{l}\text { Collaboration with other } \\
\text { consultants }\end{array}$ & - & 1 & 3 & 5 & 7 & 4.13 & 4 & 0.97 & Low \\
\hline Estimation of costs & 1 & - & 1 & 9 & 5 & 4.06 & 5 & 0.95 & Low \\
\hline Safety & - & - & 4 & 8 & 4 & 4.00 & 6 & 0.94 & Low \\
\hline Pooled & & & & & & 4.26 & & 1.00 & \\
\hline
\end{tabular}

(1) No effect; (2) worse; (3) negligible; (4) much; (5) very much. 
Table 3: Analysis of factors preventing adoption of BIM as a construction management tool. (Source: field survey, 2015.)

\begin{tabular}{|c|c|c|c|c|c|c|c|c|c|}
\hline \multirow[t]{2}{*}{ Variables } & \multicolumn{5}{|c|}{ Response } & \multicolumn{4}{|c|}{ Descriptive } \\
\hline & 1 & 2 & 3 & 4 & 5 & Mean & Rank & $\begin{array}{l}\text { Relative } \\
\text { index }\end{array}$ & Extent \\
\hline Lack of skilled personnel & - & - & 6 & 8 & 2 & 3.75 & 1 & 1.05 & High \\
\hline $\begin{array}{l}\text { Lack of internet } \\
\text { connectivity }\end{array}$ & 2 & - & 2 & 8 & 4 & 3.75 & 1 & 1.05 & High \\
\hline $\begin{array}{l}\text { Reluctance of other stake } \\
\text { holders to use BIM }\end{array}$ & - & 2 & 5 & 5 & 4 & 3.69 & 2 & 1.03 & High \\
\hline $\begin{array}{l}\text { Lack of BIM object } \\
\text { libraries }\end{array}$ & - & 2 & 4 & 7 & 3 & 3.69 & 2 & 1.03 & High \\
\hline $\begin{array}{l}\text { Lack of awareness of } \\
\text { technology }\end{array}$ & 1 & 2 & 3 & 5 & 5 & 3.69 & 2 & 1.03 & High \\
\hline $\begin{array}{l}\text { Extra costs involved in } \\
\text { hardware, software and } \\
\text { developing office } \\
\text { procedures }\end{array}$ & - & 3 & 4 & 6 & 3 & 3.56 & 3 & 0.99 & Low \\
\hline Frequent power failures & 2 & 2 & 2 & 8 & 2 & 3.38 & 4 & 0.94 & Low \\
\hline $\begin{array}{l}\text { Lack of contractual } \\
\text { documents for BIM }\end{array}$ & 1 & 3 & 3 & 7 & 2 & 3.38 & 4 & 0.94 & Low \\
\hline Fear of change & - & 4 & 6 & 3 & 3 & 3.31 & 5 & 0.92 & Low \\
\hline Pooled & & & & & & 3.58 & & 1.00 & \\
\hline
\end{tabular}

(1) For no impact; (2) for little critical impact; (3) for fairly critical impact; (4) critical impact; (5) for extremely critical impact.

Question 3: What steps need to be taken in the Nigerian construction industry so as to improve the use of BIM as a construction management tool?

The responses from the open-ended questions indicated the respondents' opinions on how the barriers could be overcome. The responses, among other issues, show the need for more support from leadership in offices, improvement in methods of construction and processes that will encourage the use of BIM. Others include: training at various levels and the provision of facilities that will stimulate the use of BIM (Table 4). Also highlighted in the responses and significant to this study is the need to increase publicity on the use of technology as tool for construction management. 
Table 4: Analysis of solutions to improve use of BIM in construction industry.

\begin{tabular}{|l|l|l|l|}
\hline Items & Frequency & Percent & Cumulative percent \\
\hline None & 10 & 62.5 & 62.5 \\
\hline $\begin{array}{l}\text { Increased Support from Leadership } \\
\text { in offices }\end{array}$ & 1 & 6.3 & 68.8 \\
\hline $\begin{array}{l}\text { Research in methods of construction } \\
\text { and processes that will encourage use } \\
\text { of BIM }\end{array}$ & 1 & 6.3 & 75.0 \\
\hline $\begin{array}{l}\text { Seminars, lectures, demonstrations } \\
\text { on use of BIM }\end{array}$ & 1 & 6.3 & 81.3 \\
\hline $\begin{array}{l}\text { The provision of basic infrastructure } \\
\text { that will promote the use of BIM }\end{array}$ & 1 & 6.3 & 87.5 \\
\hline Training and awareness & 1 & 6.3 & 93.8 \\
\hline Trainings, adaptation to changes & 1 & 6.3 & 100.0 \\
\hline Total & 16 & 100.0 & \\
\hline
\end{tabular}

\section{RECOMMENDATIONS}

Thus far, the challenges and barriers that militate against the adoption and utilization of BIM as a mechanism for handling construction in Nigerian industries have been identified. These challenges, earlier identifies include: lack of adequate support or motivation from leaders and political office holders and lack of trained personnel who are abreast of the latest development in technology. This study therefore advocates that there is the need for research that will focus on new trends and processes of construction that encourage the use of BIM. It is also imperative to create more awareness on professional bodies whose visions are related to construction and its management. Important as well is that it is important for relevant regulatory bodies to develop new processes and standards that will incorporate BIM into the procedures needed for construction.

Alufohai [15] also noted the need for government's support and involvement. In Europe and America, government has stimulated progress. Government, for instance, has a major share in construction projects in Nigeria. It can tap into this by encouraging the use of BIM in all complex government projects by giving out incentives to private firms and contractors.

Building and construction agencies should enforce the use of BIM by organizing workshops and seminars to educate stakeholders on the uses and advantages of BIM for public and private construction projects in Nigeria. To improve the industry, more research on the use of BIM as a construction management tool is necessary.

For an optimum use of BIM as construction management tool, it is important to imbibe changes in processes and behaviors. Institutional support from private industries is also needed. The leaders and relevant stakeholders in privately-established firms should key into this initiative. Equally, collaboration among stakeholders from various construction professionals will also be required to develop new processes and new methods of construction that will incorporate the integrated nature of BIM. 


\section{REFERENCES}

[1] Hassan, A. \& Yolles, H., Building information modeling, a primer. Canadian Consulting Engineer, June/July 2009, 42 pp.

[2] Abubakir, M., Ibrahim, Y., Kado, D. \& Bala, K., Contractor's perception of factors affecting building information modeling in the Nigerian construction industry. Computing in Civil Engineering, ASCE, pp. 167-178, 2014.

[3] Kiani, I., Ghomi, S.K., Alerasoul, S. \& Khoshnava, S.M., The barriers and implementation of Building Information Modeling (BIM) based on Integrated Project Delivery (IPD) in the construction industry. Conference paper February 2013, http://www.researchgate.net/publication/272789020

[4] Bynum, P., Raja R.A., Issa, F. \& Svetlana, O., Building information modeling in support of sustainable design and construction. Journal of Construction Engineering and Management, Jan. 2013.

[5] Brewer, W. \& Mendelson, M.I., Methodology and metrics for assessing team effectiveness. The International Journal of Engineering Education, 19, pp. 777-787, 2003.

[6] Chen, Y. \& Baddeley, M., Collaborative Building Information Modelling (BIM): Insights from behavioural economics and incentive theory. rics.org/research, Feb. 2015.

[7] Rajedran, S. \& Clarke, B., Building information modeling, safety benefits and opportunities. Professional Safety, Oct. 2011, 46 pp. www.asse.org

[8] Gordon, V. \& Holness, P., BIM gaining momentum, pp. 28-30, Jun. 2008. www.ashrae.org

[9] Eastman, C., Teicholz, P., Sacks, R. \& Liston, K., BIM Handbook, a Guide to Building Information Modeling for Owners, Managers, Designers, Engineer, and Contractors, John Wiley and Sons, Inc.: New Jersey, 2011.

[10] Azhar, S., Khalfan, M. \& Maqsood, T., Building information modeling (BIM): now and beyond. Australasian Journal of Construction Economics and Building, 4, pp. $15-28,2012$.

[11] Hardin, B. \& McCool, D., BIM and Construction Management, Proven Tools Methods and Workflows, Google books, 2015.

[12] Lu, W., Zhang, D. \& Rowlinson, S., BIM collaboration: A conceptual model and its characteristics. 29 $9^{\text {th }}$ Annual ARCOM Conference, 2-4 Sep. 2013, Association of Researchers in Construction Management: Reading, UK, pp. 25-34.

[13] Dim, N.U., Ezeabasili, A.C.C. \& Okoro, B.U., Managing the change process associated with Building Information Modeling (BIM) implementation by the public and private investors in the Nigerian building industry. Donnish Journal of Engineering and Manufacturing Technology, 2, pp. 1-6, 2015.

[14] Oladapo, A.A., The impact of ICT on professional practice in the Nigerian construction industry. Electronic Journal for Information System in Developing Countries, 24(2), pp. 1-19, 2006.

[15] Alufohai, A., Adoption of building information modeling and Nigeria's quest for project cost management. FIG Working Week 2012. Knowing to Manage the Territory, Protect the Environment, Evaluate the cultural Heritage, 6-10 May 2012, Rome, Italy. 